\title{
人工重力
}

\section{谷島一 嘉*}

要旨

建設中の国際宇宙ステーションから 2014 年ごろの火星有人飛行において, 長期無重力暴露に起因する循環や 骨筋肉系の退化, カルシウム錃失が大きな問題になる. 現在の対策ではなお十分でなく, 人工重力のみがこれら を網羅できる対策であると, 19世紀から考えられているものの, 地上での実験と有効性の検証が遅れている.人 工重力研究の国際的W G は 1990 年頃始まったが, 我々は将来の重要性を見越して当初から独自の小型短腕遠心 機を開発して研究を続けていた. 無重力暴露のの地上模擬実験である 6 度へッドダウン臥床を 4 日間行い, 世界 で研究者が抑えきれなかったへマトクリット值の上昇を, 毎日+ $2 \mathrm{Gz}-60$ 分の遠心負荷をかけて, 初めて抑える ことが出来た. 遠心負荷の有効性を改めて示し, 宇宙で試されるべき人工重力の一つの有力なパラメー夕を提供 した.

\section{1.はじめに}

19 世紀から 20 世紀にかけて偉大な宇宙科学者であった口 シアのツィオルコフスキーの生誕 100 年を記念して, 196 1 年にガガーリン少佐が人類として初めてヴォストーク 1 号で 宇宙空間に飛び出し, 地球を 1 周してから 40 年が経過しょう としている. 各国で宇宙に出たことのある宇宙飛行士の総数は すでに 400 人を超え, 今後ますます国際宇宙ステーションを 中心にした有人宇宙活動が本格化して行くと思われる. 一方民 間の宇宙観光旅行も，2001年初頭に予定されているミール を利用する米国人旅客の宇宙観光旅行第 1 号に始まり, おそら く2010 年か 15 年ごろには一般人を対象にかなり実用化さ れるであろう。宇宙空間での無重量体験, 宇宙から自分の国を 眺める，などの体験旅行がずっと身近になるはずである.

このような地球近傍の宇宙空間を利用する際, 人間は地上と は異なる宇宙の環境に適応して行く必要がある. 最も異なるこ とは見かけ上の無重力(実際には $10^{-4} \mathrm{G} \sim 10^{-7} \mathrm{G}$ の微小重 力は存在する)であり,これは地上では人類がほとんど経験しな い新しい環境である。もう一つの大きな違いは，この地球近傍 宇宙空間においては空気層やオゾン層による遮蔽がないため, 銀河系放射線の被爆量が増えるということである. 新しい学問 分野である宇宙医学の知見がこの 40 年の間にもたらしたもの は，新しい無重量状態に対する人体の適応のすばらしさとその 限界であり, 適応の限界は, 特に抗重力筋の不使用萎縮と, 骨

2000 年 12 月 25 日受付

*日本大学医学部衛生学・宇宙医学教室

₹ 173-8610 東京都板橋区大谷口上町 30-1

E-mail : yajima@med.nihon-u.ac.jp

キーワード：人工重力, 人間用短腕遠心機, 宇宙ステーション, 無重量

長期暴露, 循環系・筋肉系·骨量減少への対策
からのカルシウムの持続的喪失を主とした骨量減少に著しい. 筋肉に対しては運動や栄養, 薬物などである程度萎縮をカバー 出来ても, 骨に対しては人工重力を作って重力と同様な効果を 与える以外，有効な対策はないと昔から考えられていた．最近 ある種の薬剤が骨量減少に有効であることが報告されて, その 効果を確かめようとする実験が地上で宇宙模擬状態を作って計 画されているが，末だ結果が出る状態には程遠い。このほか未 知の将来の問題ではあるが, 惑星間旅行などでさらに長期間の 無重力状態が続けば, 心筋を始め全身の種々の括約筋の萎縮に よって循環系が変化したり, 免疫系や代謝系なども相応の影響 を受けることが懸念される。一種の長期隔離・閉鎖環境なので, 精神的な影響も懸念されよう。しかしながら，もし宇宙の生活 に合った人工重力装置が搭載されれば, 放射線防御や長期隔離 による精神的影響以外のこうした問題のほとんどが解決される であろうと思われる，その意味で，人工重力の今後の実用化が 切に望まれるところである。

\section{2. 人工重力の歴史と研究の変遷}

前述のツィオルコフスキーは, 1903 年, 将来の宇宙ス テーションにおいて太陽エネルギーでドライブされる回転装置 によって発生する人工重力のコンセプトを発表した. オベルス は, 1929 年, 長い索で結ばれた 2 隻の宇宙船の構想を示し た. 1952 年にはフォンブラウンによって, 直径 76 メート ルの円筒が回転する方式の宇宙ステーションが提案された. 1 959 年にはローミックが, 300 メートルの直径で 1 キロ メートルの長さの回転円筒と, その両端にそれぞれ直径 500 メートルの居住モジュールで 2 万人の収容能力を持つ宇宙ス テーションの構想を示した. 1962 年, ストーンらはこうし た遠心型の宇宙ステーションで発生するコリオリ刺激による人 間の不快感を考慮し, コリオリ効果が比較的少なくて生活でき る快適領域を提示した。彼らによる快適域の最低基準は，半径 
40 フィート，回転 0.6 ラジアン/秒であった．

1961 年, ガガーリン少佐が搭乗したヴォストーク 1 号の 打ち上げから,ソ連とアメリカは現実に人間を乗せた人工衛星 の打ち上げ競争を始め, 人工重力の概念や研究の方向も実際の 宇宙船に合うような具体性を持ち始めた. 一一方航空医学の分野 では, 第二次大戦㣪, 半径数メートル以上の大型遠心機を用い て実際にパイロットに空中戦時のような $\mathrm{G}$ をかる研究が各国 の空軍で行われていた．急降下爆撃からの引き起こし時や戦闘 機の急旋回時に発生する高 $G z$ によってパイロットが失神する 墜落事故が多発したので, それに対する乗員の高 $\mathrm{G}$ 体験や息こ らえなどによる効果的な耐 $\mathrm{G}$ 訓練，または失神を防ぐ与圧服の 改良を目的にして研究が進められた．プロペラ機からジェット 機へ,さらに高性能の戦闘爆撃機へと, マシンの進歩に従って 発生する G はどんどん高くなっていった. 高GによるL O C (意 識㕵失)の体験と耐 $\mathrm{G}$ 訓練のために, 各国空軍では 10 メートル を越す長い半径を持ち，1秒間で $10 \mathrm{G}$ 以上に達する強大な卜 ルクの遠心機を相次いで開発した。

しかしながら, 将来の宇宙船で人工重力として使用するGは もっと低い $2 \mathrm{G}, 3 \mathrm{G}$ の領域にあり, 数秒間でL OCを起こす ような目的ではなく, 30 分, 1 時間, あるいはそれ以上といっ た長い遠心負荷をかけて, いわば無重力による人体の退化と呼 ベるような, 循環系のデコンディショニング, 筋肉系の不使用 萎縮, 骨からのデミネラリゼーションなどを出来るだけ予防す る目的のものである. 空軍の強大なトルクの遠心機はこのよう な長時間使用に耐えるようには設計されていない.しかも現在 のスペースシャトルにしろ宇宙ステーションにしろミールにし ろ, 1950 年代以前にいくつか提唱されたような巨大なス テーションに比べるとはるかに小さい。ここ当分は, 直径 4 メートル, 長さ 10 メートルの円筒型のモジュール内に収納で きるような小型の遠心機でなければ実用性に乏しい.

そこで最近の人工重力の研究は, 専ら小型の遠心機を用いる

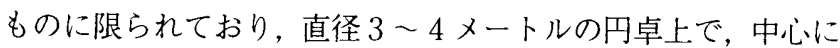
頭を向けて人間が寝て回転する方式，アームの両端に 2 台の自 転車を釣り下げ，ペダルを漕いで回転が上がると遠心力が発生 する方式, 空軍の小型版でアームの先にゴンドラを吊して回す, 半径 2 メートル以内の短腕の遠心機, などに限定されてきた. 写真 1 は当時NASAジョンソン宇宙センターに設置された円 卓型の遠心装置である.円卓上にかまぼこ型のキャビン (人間が 仰臥位で入る)が前後左右に 4 個設置されているうち, 2 個が見 えている。このような遠心機を持たない施設でも，遠心 G負荷 と類似の効果を持つ実験を工夫して, 長時間無重量暴露の地上 模擬実験で有効な対策手段や負荷時間を見出そうとする研究が 出てきた。つまり，仰臥位または 6 度へッドダウンの状態で $\mathrm{G}$ $z$ 方向にかかる Gがほぼ0であることから, 数日間以上継続す る 6 度へッドダウン臥床を宇宙の無重量状態の地上模擬と考え て，それにL B N P (下半身陰圧負荷装置)を利用して足の方に 血液を移動させたり(計算上ー $55 \mathrm{mmHg}$ 前後の陰圧が立位と 等価の $1 \mathrm{G}$ 前後の負荷に相当する), 仰臥しているベッド上で起 立させるとそれが仰臥時と比較して $1 \mathrm{G}$ 負荷と等価になること を利用した研究などである。しかしながら今までのところ，宇

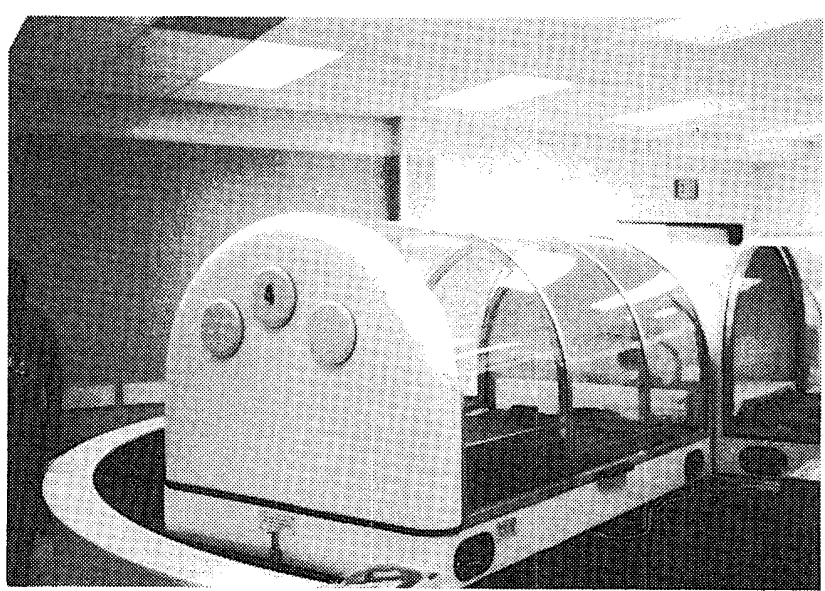

写真 1 NASA ジョンソン宇宙センターの円卓型遠心装置

宙で起こる循環系の変化を抑制することに成功した地上研究は 極めて少ない，遠心機がうまく働かないか，考える対策が十分 でないか，何らかの理由があって結果が得られていない．その 中で, 著者の日大医学部の研究のみが成果を上げていて世界の 注目を集めているので，その研究の背景と内容を紹介する.

\section{3. 小型短腕遠心機による研究}

\section{3-1 研究の背景}

1990 年にNA S Aのサルツマン, ウルフらが音頭を取り, エイムスリサーチセンターで人工重力の国際研究の第 1 回のシ ンポジウムが開かれた，各国から研究者が招かれて，重要性が 高まる 90 年以降の人工重力の国際協力による研究方法が討議 された.エイムスのベルニコス,コーヘンらがまとめ役になり， 西独(当時)から D L V L R (現D L R )のヴォクト, 米国からは バートン(米空軍)とカウダス(ベイラー大)が, 日本からは著者 が招かれた．その折の合意事項の主なものとして，1. 地上にお ける無重量模擬のスタンダードモデルとして 4 日間程度の 6 度 ヘッドダウンティルト（HDT)を採用する, 2. 各施設でできる 人工重力と等洒の負荷をそのH D Tに加えてその効果を見る, 3.効果の判定は 4 日間のHD Tに扔ける人間の変化がまちまち である中でへマトクリットだけは確実に上昇しているのでそ れを採用する，4，1年に1度づつ集まる，というようなもので あった。翌年は 5 月の米国宇宙航空医学会のおりにメンバーの 中の数人で会合を持って情報交換を行ったが，その直後にベル リンの壁の崩壞, ソ連邦の瓦解, バブルの崩壊など, 国際経済 を根底から摇るがす大事件が次々と起ったためいつの間にか会 合は立ち消えになってしまった。

著者はそのころ日大総長指定研究で 3 年間継続する「宇宙科 学に関する研究」の代表者になり, 人工重力研究の主役をにな う小型遠心機の製作を本郷にある第一医科(株)に依頼した。同 社は回転椅子は実績があるが遠心機は初めてで, 林重昭社長自 らと宮島設計主任と著者とで幾度も会合を重ねながら仕様を検 討し、ゴンドラを片側に，カウンターウエイトを反対側に吊す 小型省エネ型の遠心機を完成させた.タイミング良く清水建設 の渡部専務の知遇を得て同社宇宙開発室の全面的な協力が得ら 
れ, 西船橋近くの南海神にあった清水建設の実験棟の一つを宇 宙開発研究棟と命名してご提供頂いたので，その中に遠心機と コントロールルーム，隣に 2 人用のH D T の実験室を合わせて 設置することが出来た．我々の研究はこのように清水建設始め 数多くの方々のひとかたならぬご協力があって初めて実施可能 になった，写真 2 に清水建設の宇宙開発研究棟に設置し，遠心

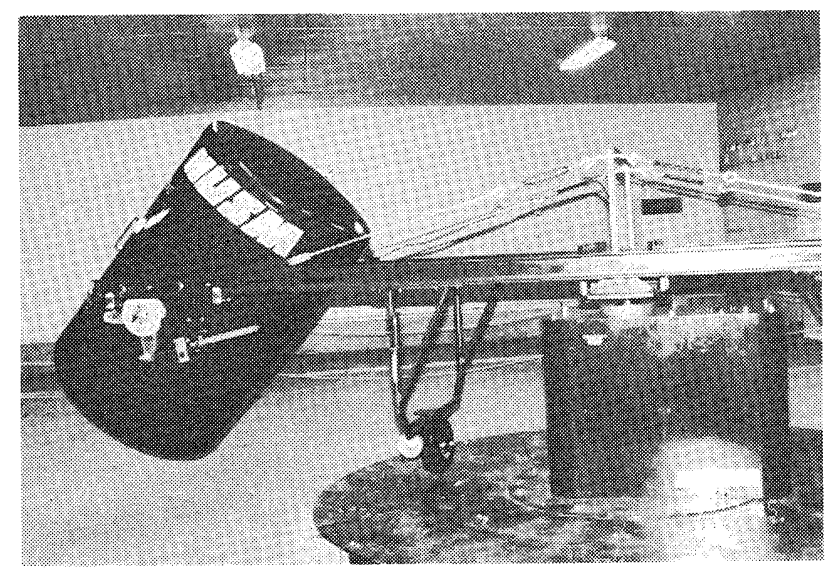

写真 2 日大医学部の短腕型遠心機 (清水建設宇宙開発研究棟にて)

実験中の日大の遠心機を示す。

\section{3-2 研究方法}

研究資金は清水建設の援助と日本大学総長指定研究費と文部 省の科学研究費補助金によった。遠心機設置, 遠心実験, HD $\mathrm{T}$ 実験, 及び冷暖房付きの宇宙開発実験棟整備から運用にかか わる一切の費用と光熱, 水道費はすべて清水建設が負担した.

このような短腕の遠心機を使用すると，1.コリオリ効果によ る前庭神経系の過剩な異常刺激による動摇病の発生, 2. 全身に かかる, 頭より足の方が高い $\mathrm{G} の$ 勾配差による予測不能の不快

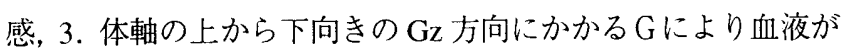
頭部, 上半身から下半身, 下肢に押しやられるための脳貧血, な どが副作用として懸念される. 実際に初期の遠心実験において はこれらの症状でしばしば実験中断を余儀なくされた. 遠心中 に少しでも頭部を動かすとコリオリ効果により頭の中がひっか き回されるような不快感が発生し，嘔吐してしまう。頭部を椅 子に固定すると今度は拘束感が次第に強く意識されて気分が悪 くなる．横隔膜が重く感じられて呼吸が苦しくなる．冷や汗が 出てきてだんだんひどくなる，脈拍が急に下がって血圧が低下 し, 前失神状態に落ち込む. 等々の例が出る度にいろいろ考え, 装置や負荷方法を改良しながら実験を続けた結果, これらの副 作用による実験中断を次第に少なくしていった．短腕の遠心機 にも大型と同じように学習効果が認められることも分かった。 1 週間毎日最大 60 分までとして遠心実験を続けると, 次第に 高い $\mathrm{G}$ と，より長時間の負荷が可能になる。 $\mathrm{G}$ と負荷時間をい ろいろ変えて実験した結果, 最終的に $\mathrm{Gz}$ 方向に $2 \mathrm{G}-60$ 分 間／日が，このような地上の遠心実験で達成し得るほぼ最大負 荷と考えられた。

次に 4 日間のH D T実験によるへマトクリット值の上昇を
我々が実施した以前のデータから取り出し, 他のH D T 実験の データを文献的に集めた上, 改めて 10 人の被験者による $\mathrm{HD}$ T実験を実施して，前述したへマトクリット值の上昇を確認し た.

新たに 1 週に 2 人づつ 5 週間かけて, 計 10 人の被験者に対 し 4 日間のHD T実験を実施した。今回はH D T中の各被験者 に対し, 毎日 $2 \mathrm{G}-30$ 分の遠心負荷を午前と午後に 2 回かけ て, 合計で 1 日に $2 \mathrm{G}-60$ 分の量の遠心負荷を与えることに よってへマトクリットの上昇が抑えられたか否かを検証した. 午前と午後の 2 回に分けた理由は, $2 G-60$ 分という負荷が 初めての人にはかなりきついが，30分位ならば耐えられると いう今までのケースを考慮し，〈り返しによる練習効果で 4 日 間の完遂を狙ったためである。

3-3 結果

10 人が 4 日間，ほぼ所定の負荷を完遂することが出来た。 初日に計 60 分でなく58 分前後で中止した例があったが， 6 0 分とほとんど等価の負荷と見なした．図１に4日間のHDT におけるへマトクリット值の\%变化を，いくつかのH D T 実験 について示した，上の方に固まる4つのH D Tのみを実施した 実験では，4日目までいずれも大きくへマトクリットが上昇し ているのに対し, 一番下のHDT+2G $z-60 \min$ 負荷実験 では, ヘマトクリットは初日に上昇したきり 4 日目まではとん

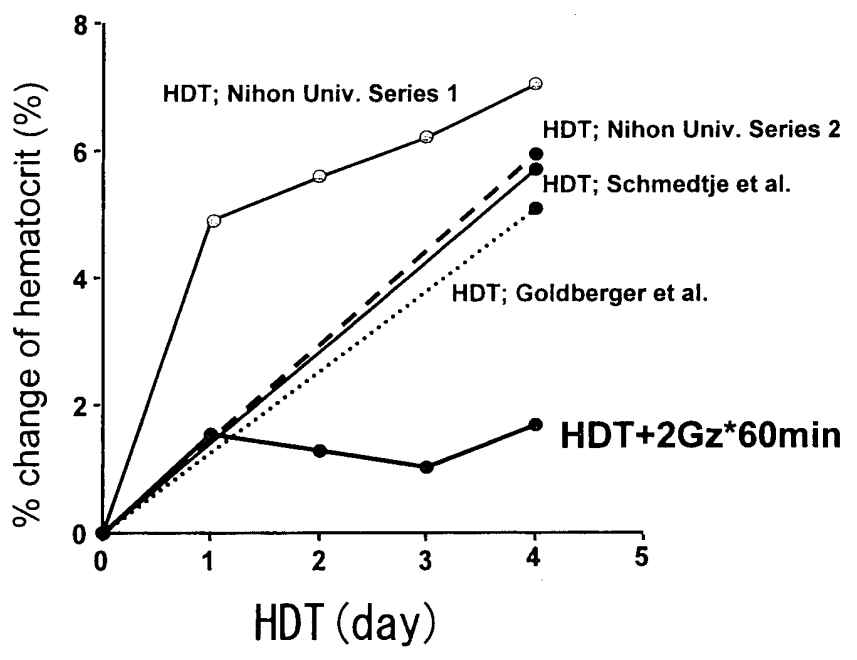

図1 HDT 4 日間に扔けるへマトクリット值の変化

ど上昇していない.ただし図には示さなかったが, 尿量 $(24$ 時 間蓄尿)は 4 日間とも次第に増加した。

\section{3-4 考察}

$\mathrm{H} \mathrm{D} \mathrm{T} \mathrm{中に} 1-2$ 時間のベッド上立位や L B N P , 付近の小 散歩程度でへマトクリット值の上昇を抑え得たデー夕は今まで にない。我々は 4 日間のHD T実験において, 毎日 $2 \mathrm{G}-60$ 分の遠心負荷を与えることによってへマトクリット值の上昇を 抑えることが出来た。このことは遠心方式の $\mathrm{G}$ 負荷が循環系の 無重力による変化に対する有効な対策であることを示すもので ある. 同時に我々が目安と考えた $+2 \mathrm{G} \mathrm{z}-1$ 時間という負荷 量が, 将来宇宙に拟いて宇宙飛行士達に人工重力負荷を実施す 
る際のパラメータの一つの基準值になることを示唆した．1日 1 時間程度の遠心負荷ならば, 宇宙ステーションや宇宙航行の 宇宙船でも毎日の運動として実施可能な時間であり，対策とし て意味をもつものである. $2 \mathrm{G}$ という負荷量については, 地上 の我々の実験ではゴンドラに座った時点で被験者に+1 G Z が かかっている。そこから $2 \mathrm{G}$ まで上げるには，つまりプラス 1 Gである，宇宙ステーションでは環境的にはほほ０Gなので,

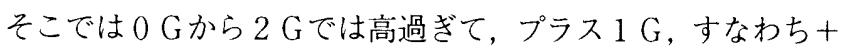
$1 \mathrm{Gz}-60$ 分という負荷が我々の地上実験上等価かそれに近 いものではないかと想像される。これこそまさにこれから宇宙 ステーションで遠心負荷を行って検証されねばならない数值で ある。

2 G-60 分はHDT 4 日目までは確かにへマトクリットの 上昇を抑えたが，24時間尿の尿量の増加は続いていた５日， 6 日と増やした場合，どこまで抑えられるかは疑問である，H D Tの日数を増やすことは今後の地上実験の一つの方向を示唆 するものであるが， $2 \mathrm{G}-60$ 分の遠心負荷に運動を加えるこ と,例えば下肢のエルゴメータを遠心負荷中に漕がせることも， 考えられる一つの方向である. 下肢の筋肉ポンプを働かせるこ とで遠心力による血液の下肢への貯留を防ぎつつ負荷量を増や す, 一石二鳥の方法かもしれない. $2 \mathrm{G}-60$ 分がかなり遠心 の限界量と思われるので, こうした負荷的な運動が工夫されて よいだろう. 実際にほとんど総ての被験者は，60分の遠心負 荷中に足に, ある人は小刻みに, ある人は時々立つ位に強く, 力 を加えて失神を防いでいた。

\section{4.おわりに}

宇宙ステーションでは当分の間動物用の遠心機しか設置しな い.人間用の遠心機が宇宙でデー夕を集めるにはまだまだ日に ちがかかりそうである.人工重力の有用性については今さらく り返す気はないが，2014 年ごろ予定されている火星ミッ ション, 6 人の宇宙飛行士が半年かけて火星に行き, 1 年半滞 在し, また半年かけて州ってくる, 地球圈以遠の壮大な有人飛 行までには人工重力が形をなして実用化されている必要がある と思う.世界的に人工重力研究の今後の発展を熱望するもので ある。

\section{参考文献}

1) Burton, R.R., A human-use centrifuge for space stations:Proposed Ground-based Studies., Aviat.Space and Environ. Med., 1998, Vol.59(6), pp.579-582.

2) Caudus, D. et al., The cardiovascular response to the AGS. Supple. to the physiologist, Vol.36(1), pp.s-155-157, 1993.

3) Polese, A., Sandler H.et al., Hemodynamic responses to seated and supine lowerbody negative pressure:comparison with $+\mathrm{Gz}$ acceleration., Aviat. Space Environ. Med., Vol.63, pp.467-475, 1992.

4) Shipov, A.A., Artificial gravity. In Space Biology and Medicine: Humans in Space flight. A.E.Nicogossian, S.R.Mohler, O.G. Gazenko and A.I.Gregoriev, Eds.Vol.3, Book2:349-363. Amer. Inst. of Aero. \& Astro.Reston, VA,1997.

5) Yajima, K.et al., Human cardiovascular and vestibular responses in long minutes and low $+\mathrm{Gz}$ loading by a short-arm centrifuge. Presented at the 10th IAA Man in Space Symposium, Tokyo, Japan, April 19-23, 1993. Acta Astronautica, Vol.33, pp.239252, 1994.

6) Fujii, T. et al., A concept for a manned artificial gravity research ship. SAE Technical Paper Series 921192, Presented at the 22nd Int. Conf. on Environ. Systems, Seattle, Washington, July 1316, pp.2-3, 1992.

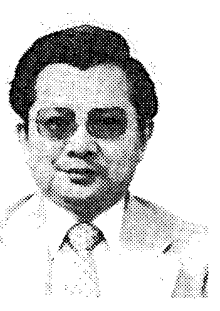

谷島一嘉 (やじまかずよし)

昭和 37 年東京大学医学部医学科卒業, 昭和 38 年東大病院インターン終了, 昭 和 42 年東京大学大学院生物系研究科 (精神医学) 修了, 同年 4 月より東京大学 医学部医用電子研究施設助手, 助教授を 経て昭和 57 年 8 月より日本大学医学部 衛生学教室教授. 平成 7 年に大学院博士課程に宇宙医学専攻 を設立. 体表面心電図, 自動車運転の疲労, 飲酒運転の研究 などのあと宇宙開発事業団の嘱託を併任し宇宙飛行士の第一 次医学選抜を主宰, 最近は宇宙医学の循環系と骨の脱カルシ ウムの対策として小型遠心機を用いた人工重力の研究を主宰. 国内では衛生学会, 宇宙航空環境医学会, 人間工学会, 交通 科学協議会などの理事, IAA（国際宇宙航行アカデミー）理 事, 米国航空宇宙医学会フェロー. 